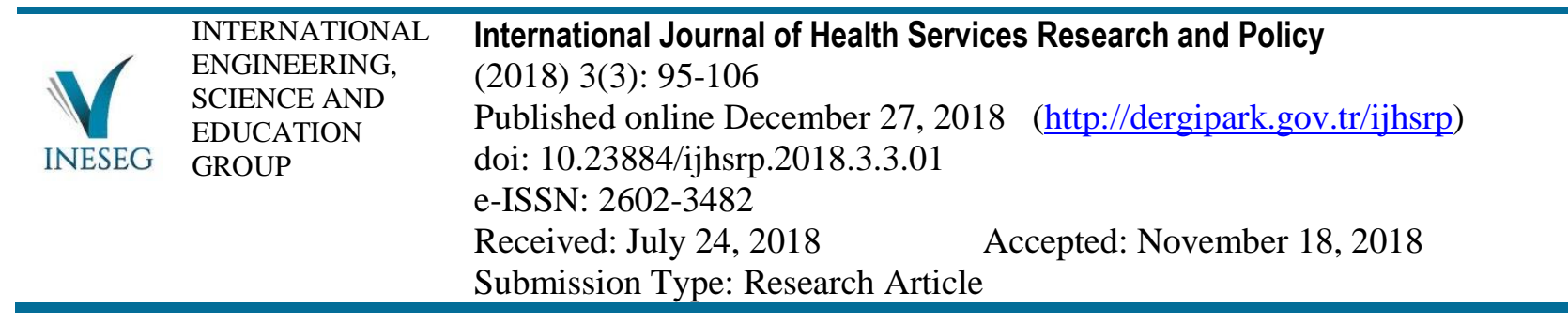

\title{
INTERESTS AND OPINIONS OF THE SOCIETY ON HEALTH NEWS AND PROGRAMS: A SAMPLE STUDY IN TRABZON
}

\author{
Assoc. Prof. Sedat Bostan ${ }^{* 1}$, Dr. Beyler Yetkiner ${ }^{2}$, Tuğba Çolak ${ }^{3}$ \\ ${ }^{1}$ Gumushane University, Health Sciences Faculty, Healthcare Management Department \\ ${ }^{2}$ İnönü University Fac. Of Communication \\ ${ }^{3}$ Trabzon Kanuni Research and Education Hospital \\ *Corresponding author; sbostan29@gmail.com
}

\begin{abstract}
Health journalism can be defined as the sharing of all kinds of health-related information, practice and development both in printed and visual media to raise public awareness. However, this sharing in health publications or news has the potential to affect the followers either positively or negatively. This study was conducted to measure the perception and effectiveness of health news and radio and TV programs on society. The study was carried out on the selected samples in Trabzon universe. The scale developed by Bostan was used and its validity was verified by exploratory factor analysis and its reliability was determined. The data was analyzed using frequency and significance tests in the SPSS program.

In print and visual media, it has been understood that audiences or readers are more likely to follow news about cancer and seasonal illnesses, as well as healthy lifestyles and innovations in healthcare. People found the health news and publications reasonably clear and effective, but not reliable enough. It was found that the confidence index of high school educated people was higher than those of other groups who had higher education levels. In other words, as the level of education increased, the confidence index decreased. Accordingly, it was suggested that the Ministry of Health should conduct a study to follow such publications and programs and make explanations when necessary.

Keywords: News, Journalism, Health, Patient
\end{abstract}

\section{Introduction}

The development of communication technologies facilitated access to information in the field of health. The sharing of health information has been encountered at any moment by means of communication tools such as TV, Radio and Newspaper. On the other hand, the information sharing related to health with these tools remains out of control. For this reason, the accuracy and scientific knowledge of the information is discussed. It has become important to investigate how citizens are affected by health news and programs and how they are reflected in their behavior. This study was carried out to contribute to meet this need. 


\subsection{News and News Values}

"News" as a term can be described as conveying the latest, most recent and remarkable information to the people about real life in an objective way [1]. News, in general, is facts and events that enable people to be informed, educated and entertained [2]. News is one of the things that human beings need and enjoy in life. This factor plays a crucial role in the sense of the future of society and individuals, in its development, in choosing the truths, in recognizing wrong and right, in the sense of itself and its environment, and finally in the integration of individuals with each other [3].

Events, phenomena, ideas or a problems are required to carry some news values so that they can be read and followed by the masses. These values constitute the basic principles of journalism [4]. The most important of the values mentioned are "Currentness, Reality, Significance and İntelligibility of Contents". These qualities arouse curiosity in the masses who are reading / watching or hearing and it is important to perceive the news in this respect. It can be said that such news generates interest and this interest is brought to our attention by experts. Expert journalism, in parallel to this, is on the agenda in recent times to increase the relevance of the masses to the news.

\subsection{Developing Expert Journalism and Health News Reporting}

With the development of today's economy, science, sociology, psychology and technology, new concepts have empathized with our world of emotion. These developments also do affect the sense of journalism, the media and publishing sectors. Especially in recent years, the concept of expert journalism is being discussed with journalists who are specialized in certain areas. Gamze Erdogan [5] states that today's journalists should always be ready to deal with any issue or inquiry, interviews and news on current issues, whether or not they are experts in their own fields, indicating that today's journalism has changed inevitably. Kucukyllmaz and Çopur [6] say that the basic knowledge of expert journalism must be known; hence, it is necessary to follow the process closely. One of the areas that needs to be closely monitored is news on the health that deals with public health.

A health news reporter working in the media sector is the person who is in charge of the relatedsubject of his/her own and who is interested in informing people about developments and innovations in the field of health [7-5] defines a health journalist as the person who communicates the print and visual media to the readers and audiences in order to enlighten them about any kind of health-related field. As for health journalism, almost every publication has its own specialist. With the emergence of health journalism, ethical violations and unsubstantiated news began to appear in news bulletins and newspaper pages. It can be said that health news reporting has substantially increased since the 90 's and that there is a visible increase in the number of health-related news of many printed-visual-digital media today [8]. People and patients learn about health-related developments and information in a big way from the media, and the media responds to the interest of those people [9]. The media is producing by developing different strategies and alternatives to improve this interest.

Nowadays, the popular newspapers are exploring the star doctors and the health news is specifically published by doctors and specialists. [10]. Patients who are aware of this have started to use media to attain their own health [11]. According to İrfan Erdoğan, in this sense of journalism, there is a need to 
be read much as a newspaper, apart from the rating ratios [12]. With respect to this, people who follow the media in Turkey in recent years are now able to discuss new things such as: which type of leukaemia bone marrow transplant can be performed, vitro fertilization practices or how to treat with acupuncture without surgery... and so on [13]. Usually, every year those, in their own way, talking about cancer has a new so-called remedy and ironically, different secrets of the brain are solved by them. Every disease is diagnosed broadly and an ordinary plant is becoming drug. However, this is not absolutely the case and this should be particularly noted. The readers are often faced with expressions such as "miracle discovery" [14]. Tunçel and his colleagues [8] have pointed out that these reports mostly refer to the daily lives of individuals, not the social and public aspects of the subject, adding the cosmetic health issues that are mostly shown in the news. It can be said that this causes some problems. Especially wrong information brings inevitable problems. Sezgin states that the situation that may be caused by this false information is as follows: It may lead to new diseases, unwanted situations including death, increase treatment costs as a result of misunderstanding about health and health culture [15]. "From this point of view, it is considered very important for the media to act in accordance with ethical values in terms of health communication." [11]. As for the media and human health, we see that there are different studies about this phenomenon.

When looked at the studies related to the subject, it is found that the media-health relationship is frequently discussed. In her study "The role of health communication in the medicalization of health", İnce Çınarlı " has reached the conclusion that the human health is commoditized by the news' contents and this can have negative consequences [16]. Birsen and Şentürk [10] say that the news made is evaluated in the context of "consumer culture" in their work titled "Health News from the perspective of Consumer Culture". Yıldız and Tanyıldızı [17] in their study titled "The health news in 2012 in Turkey and the way they were handled in national print media, as well as their informative levels in national daily newspapers- Habertürk, Hürriyet, Posta, Sabah and Sözcü“ emphasized that in a sixmonth period, a total of 480 health-related news articles were appeared in the newspapers. However, from their point of view, this number was inadequate compared to the other news reports although 96 percent of them were convincing. On the other hand, in her study "Health Communication, Media and Ethics: Analysis of An Health News" Hülür states the fact that people benefit from the media; yet, she adds that irresponsible misinformation, sometimes, is offered to people that could lead to ethical violations [11].

In another study from Öztürk ve Birsen (2013) titled " Health News from the perspective of Consumption Culture ", It was found that 56 news items published in the Hürriyet Daily which were examined at certain intervals during two days of the week and one for the weekend day came true. These included diet and nutrition, chronic diseases, aesthetics and beauty, gynaecological diseases, healthy lifestyle advice and sexuality." Similarly, Demir [13] conducted a content analysis of a total of 194 articles in his study and stated that people are very interested in health issues and are closely following at least a few of the publications in this field. Sezgin insisted in his study of "understanding health literacy", which examines health and health news, that the mass media has an important role to play in the rapid flow of information about health [15]. 


\section{Method}

\subsection{Sample}

Within the scope of the research purpose and constraints, a research with easy sampling method was carried out in Ortahisar with a population of 327 thousand, which is the central district of Trabzon universe. Only 286 surveys were available due to limitations such as the return of distributed surveys, incomplete questionnaires, and so on. By using the formula $\mathrm{n}=\mathrm{N}_{2} \mathrm{pq} /\left(\mathrm{d}_{2}(\mathrm{~N}-1)+\mathrm{t}_{2} \mathrm{pq}\right)$ [19], the sample size to represent the parent mass (Trabzon universe) reached 271 personality samples, with an acceptable 0,05 error level and $\alpha=0,10$ confidence level. The demographic characteristics of the people included in the sampling are given in table 1 . The number of men and women samples is very close to each other. In the age distribution, there are a majority of people aged 26-35 and over 46 years old. About twothirds of the people are married. High school and college graduates were in the forefront due to numerical superiority. They were mostly housewives, civil servants and workers. In addition, a local media group of 69 employees were involved in the survey to understand how far the media workers' opinions differed from the others.

Table 1. Demographic Characteristics

\begin{tabular}{|c|c|c|c|c|c|}
\hline Occupations & $\mathbf{n}$ & $(\%)$ & Education & $\mathbf{n}$ & $(\%)$ \\
\hline 1. Worker & 44 & 15,5 & 1. Primary school & 38 & 13,4 \\
\hline 2. Unemployed & 14 & 4,9 & 2. High school & 96 & 33,8 \\
\hline 3. Civil Servant & 51 & 18,0 & 3. Vocational High School & 43 & 15,1 \\
\hline 4. Tradesman & 6 & 2,1 & 4. Graduate & 94 & 33,1 \\
\hline 5. Housewife & 63 & 22,2 & 6. Postgraduate & 13 & 4,6 \\
\hline 6. Retired & 37 & 13,0 & & & \\
\hline 7. Media Worker & 69 & 24,3 & & & \\
\hline$\underline{\text { Age }}$ & & & Gender & & \\
\hline 1. $\leq 25$ & 50 & 17,6 & 1. Male & 140 & 49,3 \\
\hline 2. $26-35$ & 89 & 31,3 & 2. Female & 144 & 50,7 \\
\hline 3. $36-45$ & 51 & 18,0 & & & \\
\hline \multirow[t]{3}{*}{ 4. $46+$} & 94 & 33,1 & Marital Status & & \\
\hline & & & 1. Single & 92 & 32,4 \\
\hline & & & & 192 & 67,6 \\
\hline
\end{tabular}

\subsection{Scale, Validity and Reliability Analysis}

The questionnaire that constituted the research scale was developed by Bostan after making a literature survey and by taking the opinions of the media and health experts. The questionnaire contained items questioning 9 demographic characteristics and five Likert-type scale items about the perception of 20 health reports and television programs. Five-point Likert scale items are as follows; I do not agree at all, I fully agree with a level of participation score between 1-5. Negative items were converted into 
positive during the analysis phase, and the point values were changed in the same direction. Three (3) mean score was taken as basis in interpreting the arithmetic means in the frequency analysis. It is suggested that the structural validity of the scale also encompasses other types of validity (surface, content, criterion, merger and separation) [20]. In parallel with this approach, Exploratory Factor analysis was used to test the structural validity of the scale.

According to the result of exploratory factor analysis; out of a total of 20 items on the health news and radio/television programs evaluation scale, $\mathbf{6}^{\text {th }}, 7^{\text {th }}, \mathbf{1 6}^{\text {th }}, \mathbf{1 9 t}^{\text {h }}$, and 20 th items were removed and the remaining 15 items were combined under 3 factors.

In terms of being the conceptual aspects, clarity, reliability and efficacy were the factors taken into consideration while classifying the health news and media programmes. While the obtained factor structure explained $48,556 \%$ of the total variance, the clarity $(21,766 \%)$, the reliability $(13,762 \%)$ and the efficacy $(13,018 \%)$ became the factors with the greatest explanatory power, respectively. When the factor loadings of the items were examined, it was seen that these loads varied between 0,361 and 0,806. The Barlett sphericity test- Approx. Chi-Square: 853,499 ve df: 105 (P: 0,000)- for assessing the suitability of the data for factor analysis was seen to meet the assumption that data should not come from unit matrices [21]. KMO sampling adequacy criterion $(0,795)$ also indicated the suitability of the data. The Cronbach's Alpha statistic was calculated to be 0.757 for the whole scale.

Table 2. Factor Analysis

\begin{tabular}{|c|c|c|c|}
\hline & \multicolumn{3}{|l|}{ Factors } \\
\hline & \multicolumn{3}{|c|}{ Health news and the media programmes } \\
\hline & Reliability & Clarity & Efficacy \\
\hline s1 & & ,745 & \\
\hline $\mathrm{s} 2$ & & ,806 & \\
\hline s3 & & & ,361 \\
\hline s4 & &, 539 & \\
\hline s5 & & ,396 & \\
\hline s8 & ,670 & & \\
\hline s9 & 654 & & \\
\hline $\mathrm{s} 10$ & 697 & & \\
\hline s11 & ,724 & & \\
\hline s12 & ,698 & & \\
\hline s13 & ,732 & & \\
\hline s14 & & &,- 501 \\
\hline $\mathrm{s} 15$ & & &, 578 \\
\hline s17 & & & ,717 \\
\hline s18 & & & ,696 \\
\hline
\end{tabular}


As for the analysis of the findings, frequency and significance analyses were performed using the SPSS program. Significant differences between independent variables and dependent variables were analyzed with T-test and ANOVA tests and in post hoc analysis Tukey test was used.

\section{Findings}

The subjects issued in the survey are categorised as below:

1- The healthcare issues

2- Media devices and how often people follow the news on healthcare

3- The frequency of receiving health care services

Table 3. Status of people following health news and programs

\begin{tabular}{|c|c|c|c|c|c|}
\hline $\begin{array}{l}\text { Top five topics } \\
\text { 1. Cancer } \\
\text { 2. Healthy life } \\
\text { 3. Reproduction } \\
\text { 4. Seasonal diseases } \\
\text { 5. Innovations } \\
\text { 6. Other }\end{array}$ & $\begin{array}{l}\underline{\mathbf{n}} \\
285 \\
429 \\
50 \\
235 \\
322 \\
30\end{array}$ & $\begin{array}{l}\frac{(\%)}{21} \\
32 \\
4 \\
17 \\
24 \\
2\end{array}$ & $\begin{array}{l}\text { The first three media devices } \\
\text { 1. TV } \\
\text { 2. Internet } \\
\text { 3. Newspapers }\end{array}$ & $\begin{array}{l}\underline{\mathbf{n}} \\
481 \\
331 \\
168\end{array}$ & $\begin{array}{l}\frac{(\%)}{44} \\
30 \\
15\end{array}$ \\
\hline $\begin{array}{l}\text { Level of follow-up } \\
\text { 1. Everyday } \\
\text { 2. A couple of times a } \\
\text { week } \\
\text { 3. When there is } \\
\text { something worth } \\
\text { watching } \\
\text { 4. When I have a health } \\
\text { problem } \\
\text { 5. Never }\end{array}$ & $\begin{array}{l}83 \\
160 \\
290\end{array}$ & $\begin{array}{l}13,4 \\
25,8 \\
46,8 \\
12,4 \\
1,3\end{array}$ & $\begin{array}{l}\text { Number of people receiving health } \\
\text { care services in the last year } \\
\text { 1. } 1-3 \\
\text { 2. } 4-6 \\
\text { 3. } 7-9 \\
\text { 4. } 10-12 \\
\text { 5. } 13+\end{array}$ & $\begin{array}{l}218 \\
207 \\
126 \\
49 \\
18\end{array}$ & $\begin{array}{l}35,2 \\
33,4 \\
20,3 \\
7,9 \\
2,9\end{array}$ \\
\hline
\end{tabular}

As shown in table 3, we see that news of healthy life and health innovations are watched the most at the rate of $32 \%$ and $24 \%$, followed by cancer and seasonal diseases, respectively. $46.8 \%$ of the people stated that they only watched health news and programs when the issue was sufficiently noticeable, while $25,8 \%$ of them informed that they watched health news and programs regularly once or twice a week. It has been understood that the rate of those visiting a health clinic 1-3 times in order to get health service within the last year is $35,2 \%$ and that of $4-6$ times is $33,4 \%$. 
Table 4. People's views on health news and programs

\begin{tabular}{|c|c|c|}
\hline Factors and Items & $\overline{\mathbf{x}}$ & SD \\
\hline Clarity of health news and programs & 3,36 & $\mathbf{0 , 6}$ \\
\hline I understand the language used. & 3,66 & 1,0 \\
\hline The subject is processed in detail. & 3,35 & 0,9 \\
\hline $\begin{array}{l}\text { I do not think there is an effort to exaggerate and just to draw attention } \\
\text { to the given information. }\end{array}$ & 3,14 & 1,0 \\
\hline Medical ethics and moral responsibility principles are paid attention. & 3,29 & 1,0 \\
\hline Reliability of health news and programs & 2,58 & $\mathbf{0 , 6}$ \\
\hline $\begin{array}{l}\text { I think that alternative treatment practices are sufficiently reliable and } \\
\text { are not intended only to make money. }\end{array}$ & 2,77 & 1,1 \\
\hline I do think the news presented as 'miracle therapy' is not deceptive. & 2,40 & 1,0 \\
\hline $\begin{array}{l}\text { I think that they are accurate and sufficient informants, and I do not } \\
\text { think people will suffer from them. }\end{array}$ & 2,65 & 1,1 \\
\hline $\begin{array}{l}\text { I think that it is not wrong to do medical treatment with the medical } \\
\text { information given by the specialists, it is not absolutely necessary to go } \\
\text { to a doctor. }\end{array}$ & 2,20 & 1,1 \\
\hline $\begin{array}{l}\text { Debators are trying to help audience solve their health problems, they } \\
\text { do not make an effort to advertise. }\end{array}$ & 2,78 & 1,0 \\
\hline $\begin{array}{l}\text { I think that the news in the media about the subject is followed by the } \\
\text { Ministry of Health and that public statements are made when necessary. }\end{array}$ & 1,99 & 1,0 \\
\hline Impact of health news and programs & 3,11 & $\mathbf{0 , 5}$ \\
\hline $\begin{array}{l}\text { People are able to choose which of the media reports are correct and } \\
\text { which are wrong. }\end{array}$ & 2,84 & 1,2 \\
\hline Enough attention given to the patient confidentiality. & 3,02 & 1,0 \\
\hline $\begin{array}{l}\text { Health-related disclosures do not fuel violence against healthcare } \\
\text { professionals. }\end{array}$ & 3,28 & 1,0 \\
\hline $\begin{array}{l}\text { Reports of violence against health workers do not increase the violence } \\
\text { against health workers. }\end{array}$ & 2,97 & 1,1 \\
\hline The information provided is useful. & 3,45 & 0,9 \\
\hline
\end{tabular}


According to Table 4; The health news and programs were found to have a clarity and efficacy over the average with 3,36 and 3,11 points, with a reliability below average of 2,58. The view that the language of the programs is understandable and that the issues are handled with careful attention to detail and ethical rules is shared above the average score.

It is noteworthy that the health news of the public media is followed by the Ministry of Health and necessary explanations are made when a misunderstanding situation arises has the lowest $(1,99)$ perception rate.

People did not participate in large scale $(2,20)$ that it would be right to undergo any treatment without going to a doctor, based solely on the current knowledge even if they are made by experts. Again, it is understood that people are not very confident that the methods presented as 'miracle treatment' are not deceptive $(2,40)$. People are not very credible in that these informants are entirely correct and sufficient, and they are not sure whether or not they will be the victims of them. $(2,65)$.

People are significantly involved in the opinion that health news and programs are useful for them despite all $(3,45)$. The view that health-related programs do not cause violence against healthcare professionals is also at the forefront and the opinion that patient confidentiality is paid attention above the average has also been determined. People, however, participated below the average on the fact that violence reports on health do not increase the violence in health $(2,97)$ and that people can correctly and accurately distinguish between right and wrong $(2,84)$.

That all of the issues in which the opinions of the people are differed in terms of the confidentiality of news sources and their being confusing somehow is also remarkable. It is understood that age, education level and professional differences can be regarded as the factors that affect the confidence in health news and publications.

Tablo 5. Significant Differences showing Confidence Factors According to Independent Variables

\begin{tabular}{|c|c|c|c|c|c|c|}
\hline $\begin{array}{c}\text { Independent } \\
\text { Variables }\end{array}$ & Factors & $\mathbf{N}$ & $\overline{\mathbf{x}}$ & SD & $\mathbf{F}$ & $\mathbf{P}$ \\
\hline \multirow{4}{*}{ Age } & 25 and under & 50 & 2,7433 & ,79910 & \multirow{4}{*}{2,923} & \multirow{4}{*}{,034* } \\
\hline & $26-35$ & 89 & 2,3408 & ,76083 & & \\
\hline & $36-45$ & 51 & 2,4510 & 62919, & & \\
\hline & 46 and over & 94 & 2,4610 & ,83902 & & \\
\hline \multirow{2}{*}{$\begin{array}{c}\text { Educational } \\
\text { Status }\end{array}$} & $\begin{array}{c}\text { Primary } \\
\text { school } \\
\text { graduate }\end{array}$ & 38 & 2,4912 & ,79502 & \multirow{2}{*}{2,548} & \multirow{2}{*}{,028* } \\
\hline & $\begin{array}{l}\text { High school } \\
\text { graduate }\end{array}$ & 96 & 2,6475 & ,86998 & & \\
\hline
\end{tabular}




\begin{tabular}{|c|c|c|c|c|c|c|}
\hline & $\begin{array}{l}\text { Associate } \\
\text { degree }\end{array}$ & 43 & 2,3566 & ,75731 & & \\
\hline & $\begin{array}{c}\text { Bachelor's } \\
\text { degree }\end{array}$ & 94 & 2,3936 & 69983 & & \\
\hline & $\begin{array}{l}\text { Master's } \\
\text { degree }\end{array}$ & 13 & 2,0513 & ,77096 & & \\
\hline \multirow{7}{*}{ Occupation } & Worker & 44 & 2,7045 & 61827, & \multirow{7}{*}{3,722} & \multirow{7}{*}{, $001 *$} \\
\hline & Unemployed & 14 & 2,7738 & 57217, & & \\
\hline & Civil servant & 51 & 2,1176 & 64143, & & \\
\hline & Tradesman & 6 & 1,9722 & ,85256 & & \\
\hline & Housewife & 63 & 2,5979 & 93739, & & \\
\hline & Retired & 37 & 2,5315 & 86499, & & \\
\hline & Media worker & 69 & 2,4179 & .70225 & & \\
\hline
\end{tabular}

As is shown in Table 5, the confidence index of young people aged between 26-35 on health news and programs differs from the other groups, especially from those of 25 and younger, with the lowest average confidence level of 2,34 points. When considered from the educational point of view, the highest level of confidence in the health news is that of high-school graduates with an average of 2,64, while the confidence level, which is down to 2,05 in average, is gradually decreasing in those with higher education. The confidence in the health news is understood to have the lowest level of confidence in the civil servants $(2,11)$ and the tradesmen $(1,97)$ when examined from the point of occupation. In particular, civil servants are significantly less confident about the information given in the health news compared to housewives. There was no significant difference in terms of gender and marital status.

\section{Discussion}

This study was conducted in the Trabzon universe to enable people to evaluate the health news and programs and tried to measure the intelligibility, reliability and efficacy of the programs in its content. The results apply to their own sample and universe. Comparisons with similar investigations on this subject have been given below:

As Hülür emphasized in his study "Health Communication, Media and Ethics: Analysis of a Health News", the fact that people benefit from health news on the media, except for the ethical violation, was supported by our work [11].

In their study titled "Health News in the Context of Consumer Culture", Öztürk ve Birsen (2013) stated that the distribution of the news was in the form of dietary and nutrition, chronic diseases, aesthetics and healthy lifestyle. In our study, people also expressed greater interest in publications related to healthy life, health innovations, seasonal diseases and cancer. 
Tunçel and his colleagues [8] pointed out that health reporting, especially misinformation, might be a problem; in parallel, the fact that the low reliability of health journalism according to our study supports similar possibilities. Kaya and his colleagues [9] stated that people and patients' health-related knowledge are largely being learned from the media and the media also responds to this interest. Our survey supports this claim as well.

\section{Conclusions and Recommendations}

It has been understood that people are most likely to follow the news on healthy lifestyle and health innovations, along with cancer and seasonal diseases on visual and print media. The people have been found to be following health news and programs both in printed or visual media several times a week or just when media devices get their attention.

People find health news and programs to be reliable under average while they find them clear and effective above average. Especially, the language that is used, for them, is understandable and avoiding the healthcare terminology dominated by Latin in these programs is also important. Because, one of the important reasons of medical information asymmetry is that it has its own Latin jargon. Health news programs seem to have solved this problem. A detailed examination of the issues has also been found to be positive for the people to have in-depth knowledge in healthcare. The positive perception that citizens are avoiding from exaggerations and that they are paying attention to ethical rules can be seen as another success of health news.

Nonetheless, people have cause for cautious optimism due to monetization and advertising efforts and so-called miracle treatment approaches being effective in making health news; accordingly, they think the information provided may not be valid and accurate for everyone. This attitude can, in fact, be evaluated positively for the health of the people and healthcare system. It has been found that the confidence of the young people aged between 26-35 in health news and programs is lower than other age groups. The high school graduates have higher confidence indices than the other groups and it has been seen that the key element of confidence has fallen in those of higher education graduates. It was understood that especially civil servants find the content of their health news to be less reliable, compared to workers and housewives.

People find the information provided in health news and TV or radio programs primarily useful. In general, according to the findings of health news and programs, it can be said that the news on media does not lead to any kind of violence. However, it can be interpreted as a sign that the news of violence may have negative adverse effects on health. The people are cautiously optimistic about how much attention has been paid to patient privacy in printed or visual media and hope to be informed more about right and wrong. As a result, it is recommended that the Ministry of Health should conduct a study to follow such news publications and programs closer and make necessary explanations when needed.

\section{REFERENCES}

[1] Dursun, Ç. The drawbacks of the statement: "The News is the Mirror of Truth". ("Haber Gerçeğin Aynasıdır” Benzetiminin Sakıncaları.) (Compiled by Sevda Alakuş). Thinking about news and journalism. (2nd edition). Istanbul: IPS Communications Foundation Publications, 71-90, 2005.

[2] Girgin, A., Printed Press Release. (Yazll Basında Haber.) 2nd Edition. İstanbul: İnk1lap Publishing House, 2003. 
[3] Uğurlu, F., and Öztürk, Ş., Television Journalism in Turkey. (Türkiye'de Televizyon Haberciliği.) Konya: Tablet Bookstore, 2006.

[4] Bülbül, R., News Anatomy and Basic Approaches. (Haberin Anatomisi ve Temel Yaklaşımlar ) Ankara: Nobel Publication Distribution, 2001.

[5] Erdoğan G., Expert Journalism Practices of Culture and Arts Journalism in Mainstream and Idea Journals in National Print Media. (Ulusal Yazll Basında Uzman Gazetecilik Kültür Sanat Haberciliğinin Ana Akım ve Fikir Gazetelerindeki Uygulamaları.) Unpublished PhD Thesis, Izmir: Ege University Social Sciences Institute, 2007.

[6] Küçüky1lmaz, M. M, and Çopur, H., International Journalism in Turkish Press: A Critical Approach. (Türk Basınında Dış Habercilik: Eleştirel Bir Yaklaşım.) Issue: 35 / Naci Bostanci Special Issue-Fall / 121, 2012.

[7] Çağlar Ş., Health News Reporting. (Sağl1k Haberciliği.) Istanbul University Communication Faculty, Magazine Issue, 23, pp. 111-115, 2005.

[8] Tunçel, M. Vuran Doğan Ö. and Çobaner, A. A., Understanding the View of the Media to the Performance System: A Research on Health News on Performance. (Performans Sistemine Medyanın Bakışını Anlamak: Performans Konulu Sağlık Haberleri Üzerine Bir Araştırma.) Performance and Quality 1, S, 9-118, 2012.

[9] Kaya, A., Yüksel, E. and Öğüt, P., "Miracle Therapy" in Health News. (Sağlık Haberlerinde "Mucize Tedavi”'ler) Selçuk University Communication Faculty Academic Journal, Volume 7, Number 2 49-64, 2012.

[10] Birsen, Ö. and Öztürk, A. G. Ş. Y., Healthcare News from the point of Consumer Culture. (Tüketim Kültürü Çerçevesinden Sağlık Haberleri.) Akademik Bakış Dergisi, Number, 26. P. 1-21, 2011. [11] Hülür, A. B., Health Communication, Media and Ethics: Analysis of a Health News. (Sağlik İletişimi, Medya ve Etik: Bir Sağlık Haberinin Analizi.) Celal Bayar University Journal of Social Sciences, number, 1, S, 155-178, 2016.

[12] Erdoğan İ, Monopolization, Media and Media Practices. (Tekelleşme, Medya ve Medya Pratikleri.) Journal of Society and Physicians. s. 417-424, 2002.

[13] Demir, M., The Impact of Published Health News on Public Opinion. (Yazılı Basında Yayınlanan Sağllk Haberlerinin Kamuoyuna Etkisi.) Unpublished PhD Thesis, Ege University Social Sciences Institute (2008).

[14] Öz, E., Health literacy, "Health literacy in the eyes of the health journalist"( Sağglk Okuryazırllğgl, "Sağlık Habercisinin Gözünden Sağlık Okuryazarlığı") (Editors, Filiz Yıldırım, Alev Keser). Ankara University Faculty of Health Sciences Publication No: 3, S, 91-99, 2015.

[15] Sezgin, D., Understanding Health Literacy. (Sağlık Okuryazarlığını Anlamak.) Galatasaray University Communication Journal, No. 3, pp. 73-91, 2013.

[16] Çınarlı, İ., "The Role of Strategic Health Communication in the Medicalization of Health".( "Stratejik Sağllk İletişiminin Sağlığın Tibbileştirilmesindeki Rolü”.) Communication Theory and Research Journal, Issue, 4, S. 203-216, 2016.

[17] Yildiz, İ. and Nural İ. T., "National Print Media Buying Formats in place of the Year 2012 in Health News Turkey and Disclosure Levels (Haberturk, Hurriyet, Mail, Sabah, National Daily newspaper samples)." ("Türkiye'de 2012 Yılında Sağlık Haberlerinin Ulusal Yazılı Basında Yer Alış Biçimleri Ve Bilgilendirme Düzeyleri (Habertürk, Hürriyet, Posta, Sabah ve Sözcü Gazeteleri Örneği)." Journal of Social Sciences, Issue, 2, pp. 122-141, 2015. 
[19] Baş, T., "Questionnaire: How to Prepare, Implement, Evaluate Questionnaire".(“Anket: Anket Nasıl Hazırlanır, Uygulanır, Değerlendirilir?”.), Seçkin, 5th Edition, Ankara, 2008.

[20] Şencan, H., Reliability and Validity in Social and Behavioral Measurements. (Sosyal ve Davranışsal Ölçümlerde Güvenilirlik ve Geçerlilik.), Seçkin, Ankara, 2005.

[21] Albayrak, A. S., Applied Multivariate Statistical Techniques. (Uygulamalı Çok Değişsenli Istatistik Teknikleri.) Ankara: Asil Broadcast Ditribution, 2006. 